\title{
GOMMENTS
}

\section{WORKERS' COMPENSATION AND GRADUAL STRESS IN THE WORKPLACE}

\author{
GlenN M. Troosti
}

As medical science's understanding of mental disorders has improved, ${ }^{1}$ the relationship between stress and all kinds of disabilities, both physical and mental, has become better understood. Researchers have identified the workplace as a major source of stress, ${ }^{2}$ and courts have with increasing frequency faced claims by disabled workers seeking workers' compensation for alleged mental injuries. Although all workers' compensation claims involving mental injuries have created problems for the courts, the most troublesome cases involve psychiatric illnesses or injuries that are claimed to result from the gradual effects of everyday, on-the-job stress and anxiety. ${ }^{3}$ This Comment focuses on the

† B.S. 1983, Cornell University; J.D. Candidate, 1986, University of Pennsylvania. The author wrote this Comment while a student at the University of Pennsylvania Law School.

I See LaDou, Mulryan \& McCarthy, Cumulative Injury or Disease Claims: An Attempt to Define Employers' Liability for Workers' Compensation, 6 AM. J.L. \& MED. 1, 2-3 (1980); Marks, Defense of Psychiatric and Heart Claims Under Workmen's Compensation, 30 FED'N INs. Couns. Q. 289, 289-90 (1980). See generally Comment, Workmen's Compensation Awards for Psychoneurotic Reactions, 70 Yale L.J. 1129 (1961) (examining existing doctrines underlying traditional workmen's compensation statutes and the psychoanalytic theories increasingly used to support disability payments for psychoneurotic disorders).

2 See, e.g., Pesci, Stress Management: Separating Myth from Reality, PERsonnel AD., Jan. 1982, at 57; Rice, Can Companies Kill?, Psychology Today, June 1981, at 78; Selzer, Psychological Stress and Legal Concepts of Disease Causation, 56 CoRNELl L. Rev. 951 (1971); Waldholz, Stress Increasingly Seen as Problem, with Executives More Vulnerable, Wall St. J., Sept. 28, 1982, at 37, col. 6; Lublin, On-the-Job Stress Leads Many Workers to File-and Win-Compensation Awards, Wall St. J., Sept. 17, 1980, at 33, col. 6 .

3 Generally, cases involving mental injuries can be divided into three categories: (1) injuries caused by physical stimuli resulting in mental manifestations; (2) injuries caused by mental stimuli resulting in physical manifestations; and (3) injuries caused by mental stimuli resulting in mental manifestations. See 1B A. LARSON, THE LAW OF WORKMEN's COMPENSATION §§ 42.20-.24 (1982 \& Supp. 1983); Larson, Mental and Nervous Injury in Workmen's Compensation, 23 VAND. L. REv. 1243, 1243 (1970); Render, Mental Illness as an Industrial Accident, 31 TenN. L. Rev. 288, 288 (1964). They are commonly termed "physical-mental," "mental-physical," and "mentalmental" claims, respectively. See, e.g, 1B A. LARSON, supra, § 42.23 .

One may further divide mental-mental injuries into those caused by gradual or 
appropriate legal standard courts should apply when considering these "gradual stress" claims.

Gradual-stress cases have posed serious problems for many courts because they differ significantly from traditional workers' compensation cases. In the past, courts relied upon the presence of a traumatic precipitating event and a physically evident disability to assure them that the injury was both genuine and work-related. In a gradual-stress case, however, such indicia are absent, and the courts have been forced to fashion new tests in order to determine whether a mental injury is work-related and thus compensable.

Two principal tests have emerged. Under the approach adopted by a growing number of jurisdictions, an employee can recover workers' compensation if she can demonstrate that her mental disorder was caused by her workplace exposure to unusual, unexpected, or extraordinary stress-pressures and tensions in the workplace that are greater than those experienced by the average employee. Thus, under. this "unusual stress" test, an employee's recovery depends not only on whether gradual stress actually caused her injury, but also on whether the stress she suffered differed from that experienced by her co-workers. The competing test-the "objective causation" test-simply requires the disabled worker to establish a causal connection between the workplace and the mental injury; she need not establish that the stress that caused the injury is unusual or extraordinary.

This Comment argues that the objective causation test is the more appropriate test for determining whether workers alleging gradualstress injuries should receive benefits. This test is preferable for two reasons. First, it is more consistent with the policies of comprehensive coverage that animate workers' compensation statutes. Second, the unusual-stress test is predicated on a misguided view of causation, and often will deny compensation to claimants whose injuries are in fact work-related. The objective causation test assures that all disabled workers receive compensation for their mental injuries while it also provides adequate protection against fraudulent claims.

cumulative mental stimuli-chronic stress, for instance-and those caused by sudden or traumatic mental stimuli, such as the witnessing of the violent death of a co-worker. Although this distinction may be suspect for medical purposes, see Selzer, supra note 2, at 952, 955 (arguing that continual emotional stress may be as traumatic as a distinct mental shock), it is useful for analyzing judicial approaches to the concept of mental injuries. 


\section{Judicial Treatment of Mental-Stress Gases: The Competing Tests}

Most jurisdictions have workers' compensation statutes that their courts have interpreted to compensate workers for mental injuries associated with mental stimuli. ${ }^{4}$ In an effort to decide whether gradualstress injuries qualify as compensable mental injuries of this type, many of these jurisdictions have developed two significantly different tests: the unusual-stress test and the objective causal-connection test. ${ }^{5}$

4 A number of jurisdictions whose compensation schemes have been held not to reach gradual-stress injuries have allowed the same schemes to compensate sudden mental-mental claims. See, e.g., Albanese's Case, 378 Mass. 14, 18, 389 N.E.2d 83, 86 (1979) (stating that employee is entitled to compensation when she suffers mental disorder caused by series of identifiable, stressful, work-related incidents but not when similar injury was the product of normal wear and tear); Estate of Babb v. GTE Sylvania, Inc., 417 So. 2d 545, 550 (Miss. 1982) ("Workmen's Compensation Law in Mississippi . . requires a physical injury or traumatic impact which results in the mental condition."); Transportation Ins. Co. v. Maksyn, 580 S.W.2d 334, 338 (Tex. 1979) (barring recovery for mental disorder caused by nonphysical stimulus unless the disorder is "traceable to a definite time, place, and cause"). Most commentators agree, however, that the distinction between gradual and acute stress is unprincipled, both medically, see, e.g., Selzer, supra note 2, at 952-58, and legally, see, e.g, 1B A. LARSON, supra note $3, \S 42.23$ (b) (arguing that distinction is "unsound" since under compensation law, when injury "has some physical component, the protracted nature of the stimulus has not been an obstacle to recovery").

- A third test is the subjective causal-nexus test, adopted by Michigan in Deziel v. Difco Laboratories, Inc., 403 Mich. 1, 268 N.W.2d 1 (1978). The state supreme court was faced with a worker in an automobile salvage department who, due to his hypochondria, was disabled by an irrational worry that the cars being assembled were unsafe, even though there was no objective evidence to substantiate that fear. The court held that a claimant is entitled to compensation for a mental injury if she honestly believes that an "injury incurred during the ordinary work of . . . employment 'caused" [the] disability." Id. at 26,268 N.W.2d at 11 . Compensation would thus be allowed even though the employee's subjective perception of the work environment as the cause of her disability was in fact mistaken. See id. There need not be any causal connection between the actual work conditions and the mental injury; the employee need only honestly believe that she was disabled by a work-related injury.

Such a standard undoubtedly represents the worst nightmares of any judge who fears that the compensation of gradual mental-mental cases will lead to a flood of fraudulent claims. Indeed, the "honest perception" standard was recently questioned by the Michigan Court of Appeals:

In view of the financial gain-sometimes very substantial-any person who files a claim based on a psychiatric disorder will have strong motives to lie about his perception. The question then becomes whether that perception is "honest." ... [U]nder this loose standard for recovery, Michigan employers are nearly becoming general health insurers for psychiatric disabilities. This is an alarming possibility.

Bentley v. Associated Spring Co., 133 Mich. App. 15, 20-21, 347 N.W.2d 784, 786-87 (1984) (citation omitted). Other courts that are critical of this strictly subjective nexus standard stress the importance of the work itself actually causing the injury:

We all know that stress may flow from work conditions. However, the onthe-job stress conditions causing the disorders must be real. That is, the 


\section{A. Unusual, Unexpected, or Extraordinary Stress Test}

Of the states that have addressed gradual-stress cases, nine have adopted some variation of a test that requires the claimant to establish that her injury was the result of unusual, unexpected, or extraordinary stress in the workplace. ${ }^{6}$ The approach taken by the Wisconsin Supreme Court in Swiss Colony, Inc. v. Department of Industry, Labor and Human Relations ${ }^{7}$ is illustrative. In that case, the court held that the concept of injury includes emotional stress without physical trauma if the injury results from exposure to conditions or circumstances be-

events and conditions producing the stress must, from an objective standpoint, exist in reality. . . A worker's misperception of reality does not flow from any factual work condition.

McGarrah v. State Accident Ins. Fund Corp., 296 Or. 145, 164, 675 P.2d 159, 170 (1983).

In response to Deziel, the Michigan legislature amended the workers' compensation law to preclude compensation under a subjective standard. The amendment states that " $[\mathrm{m}]$ ental disabilities shall be compensable when arising out of actual events of employment, not unfounded perceptions thereof." 1980 Mich. Pub. Acts 357 (codified at Mich. Comp. Laws ANN. § 418.301(2) (West Supp. 1984)). See Joseph, Causation in Workers' Compensation Mental Disability Cases: The Michigan Experience, 27 WAYNE L. REv. 1079, 1083-84 (1981).

6 The nine states are Arizona, Arkansas, Maine, Montana, New York, Rhode Island, Tennessee, Wisconsin, and Wyoming. See Sloss v. Industrial Comm'n, 121 Ariz. 10, 588 P.2d 303 (1978), Owens v. National Health Laboratories, Inc., 648 S.W.2d 829, 831 (Ark. Ct. App. 1983) (stating that if psychological injury results from "nontraumatically induced events . . . the worker must show more than the ordinary day-to-day stress to which all workers are subjected"); Townsend v. Maine Bureau of Pub. Safety, 404 A.2d 1014, 1020 (Me. 1979) (adopting dual test for gradual stress whereby claimant may recover if she can either demonstrate that she "was subjected to greater pressures and tensions than those experienced by the average employee or, alternatively, by clear and convincing evidence show that the ordinary and usual workrelated pressure predominated in producing the injury"); Erhart v. Great W. Sugar Co., 169 Mont. 375, 381, 546 P.2d 1055, 1058 (1976) (holding that nervous breakdown as a result of stress is compensable only if it is clearly attributable to an unusual strain and a tangible happening, or series of happenings, of a traumatic nature); In re Ottomanelli, 80 A.D.2d 688, 688, 436 N.Y.S.2d 442, 443 (App. Div. 1981) (holding that butcher's work week, which consisted of five 12-hour days, constituted "prolonged, unusual circumstances" that supported recovery in a mental-mental case); Rega v. Kaiser Aluminum \& Chem. Corp., 475 A.2d 213, 216 (R.I. 1984) (stating that employee must prove that "mental injury and disability were caused by dramatically stressful stimuli that were not ordinarily present and expected in the workplace"); Mayes v. United States Fidelity \& Guar. Co., 672 S.W.2d 773, 774 (Tenn. 1984) (holding that recovery is available only when mental or nervous disorder results from "fright, shock or even unexpected anxiety" that amounts to an "accident"); Swiss Colony, Inc. v. Department of Indus., Labor \& Human Relations, 72 Wis. 2d 46, 51, 240 N.W.2d 128, 130 (1976); Consolidated Freightways v. Drake, 678 P.2d 874, 877 (Wyo. 1984) ("[N]on-traumatically caused mental injury is compensable . . . if it results from a situation or condition in employment that is of greater magnitude than the day-to-day mental stresses and tensions all employees usually experience.").

772 Wis. 2d 46, 240 N.W.2d 128 (1976). 
yond those common to everyday worklife. ${ }^{8}$ The claimant in Swiss Colony was a purchasing agent who suffered a schizophrenic breakdown that was attributed to the nerve-wracking seasonal quality of her job and the harassments of her supervisor. According to the court, "[I]n order for a non-traumatically caused mental injury to be compensable ... [it] must have resulted from a situation of greater dimensions than the day-to-day mental stresses and tensions which all employees must experience."

Phrased differently by the Supreme Court of Tennessee, the unusual-stress test stands for the proposition that

"worry, anxiety or emotional stress of a general nature" are not, in and of themselves, sufficient to establish an accident [and] . . . that "injury by accident" does not embrace every stress or strain of daily living or every undesirable experience encountered in carrying out the duties of a contract of employment. $^{10}$

Stated as such, this test is essentially evidentiary, for the stressors present in the workplace must be so conspicuous that there is little doubt in the court's mind that such stressors actually exist and that they caused the claimant's injury. Indeed, the unusual-stress test's appealing quality seems to be that it treats gradual-stress injuries as if they were caused by an event-its requirement that some "unexpected, unusual, or extraordinary" occurrence take place is a search for discrete, isolated incidents from which the tag of "causation" may be hung.

\section{B. Objective Causal-Connection Test}

The objective causal-connection test is employed by nine jurisdictions. ${ }^{11}$ The Oregon experience is representative. In 1983 Oregon's su-

${ }^{8}$ See id. at 51, 240 N.W.2d at 130 (citing School Dist. No. 1 v. Department of Indus., Labor \& Human Relations, 62 Wis. 2d 370, 215 N.W.2d 373 (1974)).

'Id.

${ }^{10}$ Matthews v. Industrial Maintenance Corp. (Tenn. June 11, 1984) (unpublished opinion) (available Jan. 1985, on LEXIS, States library, Tenn. file) (quoting Allied Chem. Corp. v. Wells, 578 S.W.2d 369, 372 (Tenn. 1979)).

${ }^{11}$ California, Hawaii, Kentucky, Louisiana, Maine, New Jersey, Oregon, Pennsylvania, and West Virginia have adopted some version of this test. See Baker v. Workmen's Compensation Appeals Bd., 18 Cal. App. 3d 852, 861, 96 Cal. Rptr. 279, 286 (1971) (holding that psychoneurotic injuries resulting from the "cumulative effect of each day's stresses and strains" are compensable); Royal State Nat'l Ins. Co. v. Labor \& Indus. Relations Appeal Bd., 53 Hawaii 32, 38, 487 P.2d 278, 282 (1971) (holding that an "employee suffers a work-related injury within the meaning of [the statute] when he sustains a psychogenic disability precipitated by the circumstances of his em- 
preme court adopted the causal-connection test in McGarrah $v$. State Accident Insurance Fund Corp. ${ }^{12}$ Acknowledging that "[t]he vast majority of workers, if not all, face and deal with job stress on a daily basis,"13 the court held that it is only equitable that such stress, if objectively real, be recognized as a cause of compensable injuries. ${ }^{14}$

The court, however, was mindful of the caution necessitated by such a broad approach, and it articulated a two-part test. First,

[t]he stressful conditions must actually exist on the job. That is, they must be real, and not imaginary. The views of an average worker or average person or the perceptions by the claimant may be relevant, but are not determinative. The existence of legal cause of stress-related occupational disease must be determined objectively. ${ }^{15}$

Second, the claimant must prove that employment conditions, when compared to nonemployment conditions, were the "major contributing cause" of the mental disorder. ${ }^{16}$ This standard does not require that the injury be caused or aggravated solely by work conditions ${ }^{17}$ but

ployment," which need not be extreme or unusual); Yocom v. Pierce, 534 S.W.2d 796, 799 (Ky. 1976) (holding that recovery is available for nervous breakdown where claimant's pre-existing anxiety neurosis was a dormant nondisabling condition that was "aroused or brought into disabling reality" by her job as a ticket operator in a garment factory); Taquino v. Sears, Roebuck \& Co., 438 So. 2d 625, 626-27 (La. Ct. App.), cert. denied, 443 So. 2d 597 (La. 1983) (holding that cause of action exists where the claimant attributes nervous breakdown to employment pressure as long as breakdown is proven to be causally related to the claimant's employment); Townsend v. Maine Bureau of Pub. Safety, 404 A.2d 1014, 1020 (Me. 1979) (holding that recovery is available for mental anxiety resulting from unusual or extraordinary stress or where claimant can show, "by clear and convincing evidence" that "ordinary and usual work-related pressures predominated in producing the injury"); Williams v. Western Elec. Co., 178 N.J. Super. 571, 585, 429 A.2d 1063, 1071 (1981) (stating that plaintiff can recover if there is "objective evidence which, when viewed realistically, . . . demonstrate[s] that the alleged work exposure was to a material degree a contributing factor"); McGarrah v. State Accident Ins. Fund Corp., 675 P.2d 159, 170 (Or. 1983) (holding that claimant can recover for mental disability caused by work-related stress if that disability flows from work conditions that are, in reality, work-related); University of Pittsburgh v. Workmen's Compensation Appeal Bd., 49 Pa. Commw. 347, 353, 405 A.2d 1048, 1051 (1979) (holding compensable a suicide that was induced by a work-related mental breakdown which, according to the medical testimony, was the result of overwork and anxiety); Breeden v. Workmen's Compensation Comm'r, 285 S.E.2d 398, 400-01 (W. Va. 1981) (holding that employee who sustained mental and emotional injuries as a result of continuous and intentional harassment and humiliation from her supervisor suffered "compensable personal injury" within meaning of workmen's compensation act).

12675 P.2d 159 (Or. 1983).

13 Id. at 169.

14 See id. at 169-70.

15 Id. at 171 (footnote omitted).

${ }^{18} \mathrm{Id}$. at 172.

17 See id.; see also OR. REV. STAT. § 656.802(1)(a) (1981). 
only that the claimant show that the stress at work outweighed the stress experienced outside work.

Maine has adopted a slightly modified version of the simple causal-connection rule in its attempt to recognize gradual stressors in the workplace. In Townsend $v$. Maine Bureau of Public Safety, ${ }^{18}$ the claimant, a police department dispatcher, suffered a nervous breakdown after being subjected to work-related harassment by her co-workers. The dispatcher claimed that she was followed, was harassed by annoying telephone calls, was summoned to court, and was disciplined and suspended repeatedly and unjustly until she could no longer work. ${ }^{19}$ While recognizing the needs to protect the employer from fraudulent claims and to avoid transforming the employer into a health insurer, the court noted a desire to protect the "average" person and those predisposed to mental injury. Accordingly, the court adopted a dual test for identifying compensable mental injuries. When

the mental disability is the gradual result of work-related stresses, the claimant will have to demonstrate either that he was subjected to greater pressures and tensions than those experienced by the average employee or, alternatively, by clear and convincing evidence show that the ordinary and usual work-related pressures predominated in producing the injury. ${ }^{20}$

In McGarrah the Oregon court praised this analysis as "reveal[ing] an underlying methodology to counterbalance the policy problems that emanate from the subjective nature of mental injuries by providing an objective measurement."21

\section{Considerations Relevant to Choosing an Appropriate STANDARD}

The jurisdictions whose workers' compensation statutes reach gradual-stress injuries have split over the appropriate legal standard to apply when dealing with such injuries. Deciding which test is more appropriate critically affects the disposition of gradual-stress claims. True gradual stress results from the everyday psychic wear-and-tear of the job's strains and tensions; by definition it is neither unusual nor extraordinary. Consequently, a jurisdiction's adoption of the unusual-

\footnotetext{
18404 A.2d 1014 (Me. 1979).

19 See id. at 1015.

20 Id. at 1020.

${ }^{21}$ McGarrah, 675 P.2d at 165.
} 
stress test would bar many individuals who suffer gradual-stress injuries from receiving workers' compensation benefits, while its adoption of the objective causal-connection test would, in many cases, allow those same workers to obtain benefits. ${ }^{22}$

In addressing the issue of which test is preferable, one must focus on two considerations. First, one must take into account the policies underlying workers' compensation statutes. Second, one must understand the factors that have influenced courts in their approach to gradual-stress claims.

\section{A. The System's Purposes and Scope}

States enacted workers' compensation statutes in an attempt to respond to injustices that existed under common law ${ }^{23}$ and to adapt to the changes that industrialization had wrought. ${ }^{24}$ The purpose of a work-

${ }^{22}$ See, e.g., Townsend v. Maine Bureau of Pub. Safety, 404 A.2d 1014 (Me. 1979) ("While the [unusual stress test] would be appropriate in the vast majority of gradual mental injury cases, it would not compensate an individual who, for example, developed a psychological disability resulting from the simple day-to-day stresses of an assembly line .....”).

${ }^{23}$ Before the enactment of workers' compensation statutes in the nineteenth century, common-law principles controlled the ability of workers to recover for injuries they incurred during the course of their employment. Under the common-law system the worker carried the burden of establishing the employer's negligence. See National Commission on State Workmen's Compensation Laws, THe Report of THE National Commission on State Workmen's Compensation Laws 34 (1972) [hereinafter cited as National CoMm'N REPORT]. Further, the employer had three significant defenses: contributory negligence, the fellow-servant doctrine, and assumption of risk. See id.

The Wainwright Commission, appointed by New York Governor Hughes in 1909 to study the question of employer liability, found the old tort system of employer liability to be unsatisfactory because "only a small proportion of injured workmen received substantial compensation, the system was costly and wasteful, it was slow in operation and it breeded antagonism between employers and employees." NEw YORK STATE Bar Association, Report of Special Committee Appointed to Study the WORKMEN'S COMPENSATION LAW 6-7 (1957).

These common-law constraints can be attributed to the laissez-faire economic philosophy dominant in the latter part of the nineteenth century. See 1 A. LARSON, supra note $3, \S 4.30$. Employers' liability was viewed as an undesirable disincentive to the capitalist. At the same time, the worker was seen as an independent economic actor responsible for her own safety and entitled to recover for her work-related injuries only in cases of negligence. Workers' compensation statutes represented a radical conceptual departure from this economic vision and a practical response to its unfairness. The statutes focused on the particular problems presented by the common law approach. The framers of these statutes sought to eliminate the negligence requirement in order to broaden recovery. See NATIONAL COMM'N REPORT, supra, at 34.

${ }^{24}$ See 1 A. LARSON, supra note 3, $\$ 2.20$; Bernstein, Workmen's Compensation: Origins, Present Needs and Future Design, in National Institutes ON Rehabilitation and Health Services, Report of the National Workshop on RehaBILITATION AND WORKMEN's COMPENSATION 1-2 (1971) [hereinafter cited as NaTIONAL WORKSHOP REPORT]. 
ers' compensation system is to provide broad, no-fault coverage to all victims of all work-related injuries. ${ }^{25}$ The underlying rationale is one of risk-spreading and cost distribution: the economic burden of injuries within the workplace is a part of the cost of production and is therefore a business expense that should be borne by the employer, who can shift the cost to the consumer. ${ }^{26}$

The system is meant to function as a broad-based, no-fault, ${ }^{27}$ income-protection device, the quid pro quo of which is the system's guarantee of certain fixed benefits in return for the workers' relinquishment of the right to seek a higher, although less certain, award in a tort action. ${ }^{28}$ "For the employer, it represents a relatively inexpensive way to protect himself against the possibility of lawsuits for injuries to his employees. For the worker, it represents an important segment of his protection against income loss." 29

\section{B. The Evolution of Coverage of Mental Injuries}

In approving workers' compensation awards for mental injuries, the courts extended compensation first in mental-injury cases that resembled physical-injury cases and then in cases involving injuries that were more purely mental. An examination of this development is helpful, for it reveals that the principal factor that has limited the extension of coverage to mental injuries has been judicial concern that compensated injuries be genuine. This concern explains why some courts have refused to adopt the objective causal-connection test and have instead favored the unusual-stress test.

The principal requirements imposed by most state's workers' com-

${ }^{25}$ See 1 A. LARSON, supra note $3, \S 1$.

${ }^{26}$ See id.; Note, Workers' Compensation: Recovery for Psychological Disability Caused by Work-Related Stress: Lockwood v. Independent School Dist. No. 877, 66 Minn. L. Rev. 1194, 1196 (1982); see also 1 A. LARSON, supra note 3, § 2.20:

The ultimate social philosophy behind compensation liability is belief in the wisdom of providing, in the most efficient, most dignified, and most certain form, financial and medical benefits for the victims of work-connected injuries which an enlightened community would feel obliged to provide in any case in some less satisfactory form, and of allocating the burden of these payments to the most appropriate source of payment, the consumer of the product.

27 What distinguishes the workers' compensation system from other "tort-like" remedies is the imposition of strict liability. Liability is based solely on the occurrence of a disabling accident during one's work.

${ }^{28}$ See National Commission Report on State Workmen's Compensation Laws, COMPENDIUM ON WORKMEN's COMPENSATION 23 (1973) [hereinafter cited as COMPENDIUM].

${ }^{28}$ Larson, Changing Concepts in Workmen's Compensation Coverage, in $\mathrm{NA}_{\mathrm{A}}$ TIONAL WORKSHOP REPORT, supra note 24 , at 33. 
pensation statutes are (1) the employee must experience a "personal injury arising out of and in the course of employment"30 and (2) the injury must result in a disability entailing either partial or total incapacity to work..$^{31} \mathrm{~A}$ majority of state statutes also require, or have required, that the injury be "by accident." 32

The fact that much workers' compensation case law evolved during a period when most recognized industrial accidents were of a distinctly physical character, ${ }^{33}$ combined with the concrete language of workers' compensation statutes, ${ }^{34}$ has slowed judicial approval of bene-

3o National Comm'n RePORT, supra note 23, at 32.

31 See id. at 32-33.

32 1B A. LARSON, supra note 3, $\S 37.10$.

${ }^{33}$ See Bernstein, Workmen's Compensation: Origins, Present Needs and Future Design, in NATIONAL WORKSHOP REPORT, supra note 24, at 4; see also NATIONAL COMM'N REPORT, supra note 23, at 35 ("The basic principles of the present program[s] are largely those established 50 or 60 years ago; they can be completely understood only in the context of forces present at their creation.").

34 The problems presented by judicial efforts to extend statutory coverage to mental-injury cases can best be seen by examining the "by accident" requirement. Many jurisdictions have interpreted this phrase to require that, in addition to being unexpected, an accidental injury must also be traceable to a particular event or cause. See 1B A. LARSON, supra note $3, \S 37.20$.

The justification for this requirement, which a gradual-stress injury by its very nature often cannot satisfy, is questionable. The phrase "injury by accident" is taken directly from English law, which made it quite clear that the requirement "was intended to do little more than deny compensation to those who injured themselves intentionally." Compendium, supra note 28, at 30. As Professor Larson notes, there is no reason, "as a matter of grammar, to read the phrase as if it referred to 'an accident," and then proceed to conduct a search for 'the accident." "1B A. LARSON, supra note 3, $\S 37.20$.

Nevertheless, many jurisdictions do just that, and, unfortunately for those with gradual-stress claims, courts understand an "accident" to be an occurrence in which some force acts directly upon the physical structure of a worker's body and results in a readily noticeable injury. See, e.g., Bowman v. National Graphics Corp., 55 Ohio St. 2d 222, 378 N.E.2d 1056 (1978) (holding uncompensable a claimant's back injury that stemmed from a gradually worsening condition because the injury was not the result of a sudden mishap). For these courts, such a requirement must take on a new and strained interpretation in order to extend coverage to a worker traumatized but "unhurt" by an explosion, see Simon v. R.H.H. Steel Laundry, Inc., 25 N.J. Super. 50, 95 A.2d 446, affd per curiam, 26 N.J. Super. 598, 98 A.2d 604, petition for certification denied, 13 N.J. 392, 99 A.2d 859 (1953); Burlington Mills Corp. v. Hagood, 177 Va. 204, 13 S.E.2d 291 (1941), or "burned out" from a burdensome workload, see Barrett v. Arkansas Rehabilitation Serv., 661 S.W.2d 439 (Ark. Ct. App. 1983); University of Pittsburgh v. Workmen's Compensation Appeal Bd., 49 Pa. Commw. 347, 405 A.2d 1048 (1979). However, the rule in most jurisdictions today is that the "by accident" requirement is met if either the cause of the injury was accidental or the injury was the unexpected result of the routine performance of the worker's duties. See 1B A. LARSon, supra note 3, § 38.00; Note, Emotional Stress-Now a Cause of Compensable Injury?, 34 LA. L. REv. 846, 847 (1974); Comment, supra note 1, at 1139.

Even if a claimant with a mental injury establishes that the injury was "by accident," she still must negotiate the "arising out of and in the course of employment" obstacle. Virtually every state workers' compensation system imposes this requirement or some variant of it. See 1 A. LaRson, supra note 3, $\S 6.00$; NATIONAL Comm'N 
fits for workers claiming mental injuries. Courts have had little difficulty approving compensation for workers with mental injuries caused by physical stimuli or physical injuries caused by mental stimuli, ${ }^{35}$ presumably because such injuries resemble the purely physical injuries to which the courts were accustomed.

The courts have been more reluctant to allow recovery for mental injuries allegedly caused by mental stimuli. The pioneer cases in this area involved sudden frights. ${ }^{36}$ In Burlington Mills Corp. v. Hagood, ${ }^{37}$ for example, the claimant was so frightened by an electric flash that she fainted into the arms of a co-worker. The claimant associated her coworker with the frightening experience so that seeing him would cause her to faint again. The Supreme Court of Virginia held that the injury, which made it impossible for the claimant to work, was compensable. ${ }^{38}$ The key to the case was the sudden stimulus. Although nothing actually touched the claimant, the explosion satisfied the court's requirement of an "accident."

Perhaps the most significant early case was Bailey $v$. American

REPORT, supra note 23 , at 50 . This phrase is not free from its own difficulties of interpretation. The United States Supreme Court has said that this "statutory phrase . . . is deceptively simple and litigiously prolific." Cardillo v. Liberty Mut. Ins. Co., 330 U.S. 469,479 (1947).

The phrases "arising out of" and "in the course of," although combining to determine "work-connection," focus on different aspects of that standard. See 1 A. LARSoN, supra note $3, \S 6.10$. The "arising out of" clause requires that the personal injury arise "out of the nature, conditions, obligations or incidents of the employment." Note, When Stress Becomes Distress: Mental Disabilities Under Workers' Compensation in Massachusetts, 15 NEw ENG. L. REv. 287, 291 (1980). To satisfy this requirement, the worker must be injured as the result of a risk to which she was exposed as a consequence of her status as an employee. The "in the course of employment" phrase requires consideration of the time, place, and circumstances of the injury. See $1 \mathrm{~A}$. LARSON, supra note $3, \S 14.00$. "An injury is said to arise in the course of the employment when it takes place within the period of employment, at a place where the employee reasonably may be, and while he is fulfilling his duties or engaged in doing something incidental thereto." 1 A. LARsoN, supra note $3, \S 14.00$.

The potential problems inherent in these dual requirements of work connection are readily apparent. The nature of psychiatric injuries, especially those caused by gradual mental stimuli, precludes easy categorization of their cause and existence. Hard facts of where, when, and how are not likely to be easily proved. See Comment, supra note 1, at 1142-44 (arguing that the nature of certain psychoneurotic reactions makes it impossible to estimate the probability of injury occurring in the absence of employment and that the causal significance of any one factor is often impossible to determine).

35 See 1B A. LARSON, supra note 3, $\$$ 42.21-.22 (collecting cases).

${ }^{36}$ See Simon v. R.H.H. Steel Laundry, 25 N.J. Super. 50, 95 A.2d 446 (sudden fright caused by explosion of steam pipe), affd per curiam, 26 N.J. Super. 598, 98 A.2d 604, petition for certification denied, 13 N.J. 392, 99 A.2d 859 (1953); Burlington Mills v. Hagood, 177 Va. 204, 13 S.E.2d 291 (1941) (sudden fright caused by sound of electrical explosion).

37177 Va. 204, 13 S.E.2d 291 (1941).

${ }^{38}$ See id. at 211,13 S.E.2d at 294.

39 See id. at 209-10; 13 S.E.2d at 193. 
General Insurance Co., ${ }^{40}$ in which the Texas Supreme Court recognized mental-mental injuries of the sudden type despite the Texas statute's definition of " injury [as] damage or harm to the physical structure of the body." "41 The claimant and another worker were on a scaffold when one end gave way. Although he was caught by the ropes of the apparatus and was physically unharmed, the claimant saw his co-worker plunge to his death. Despite attempts to resume work, the claimant became paralyzed when trying to work at certain heights and began experiencing other nervous difficulties. ${ }^{42}$

The court addressed the statutory issue directly, holding that the worker had indeed suffered damage and harm to his body, even though the accident itself had left him unscathed. ${ }^{43}$ In exploring the nature of injury, the court reasoned that the whole man must be examined, not just the readily observable physical structure. Since the claimant's body could no longer function as a result of a mishap that he had experienced at work, the court did not hesitate to extend coverage. ${ }^{44}$

These cases are typical of the early favorable mental-mental decisions. In all there were sudden, traumatic events that precipitated subsequent injuries, and the courts relied on the occurrence of these events as indicia of causation. ${ }^{45}$

In spite of these decisions, courts in a number of jurisdictions have refused to authorize compensation for mental-mental injuries, ${ }^{46}$ even though they have authorized recovery for physical-mental and mental-

40154 Tex. 430, 279 S.W.2d 315 (1955).

41 Id. at 435, 279 S.W.2d at 318 (citing Tex. Rev. Grv. Stat. ANN. art. 8306 $\S 20$ (Vernon 1925)) (emphasis added by the court).

42 See id. at 432, 279 S.W.2d at 316.

13 The phrase "physical structure of the body," as it is used in the statute, must refer to the entire body, not simply to the skeletal structure or to the circulatory system or to the digestive system. It refers to the whole . . . . [T] he structure should be considered that of a living person-not as a static, inanimate thing.

Id. at 436,279 S.W.2d at 318.

14 See id. at 441-42, 279 S.W.2d at 322.

15 See, e.g., Pathfinder Co. v. Industrial Comm'n, 62 Ill. 2d 556, 343 N.E.2d 913 (1976) (involving claimant who witnessed co-worker's hand being severed by punch press); Wolfe v. Sibley, Lindsay \& Curr Co., 36 N.Y.2d 505, 330 N.E.2d 603, 369 N.Y.S.2d 637 (1975) (involving claimant who discovered body of supervisor who had committed suicide).

46 Five jurisdictions-Florida, Georgia, Kansas, Minnesota, and Oklahoma-still deny coverage in all mental-mental cases. See Williams v. Hillsborough County School Bd., 389 So. 2d 1218 (Fla. Dist. Ct. App. 1980); Hanson Buick, Inc. v. Chatham, 163 Ga. App. 127, 129, 292 S.E.2d 428, 429-30 (1982); Followill v. Emerson Elec. Co., 234 Kan. 791, 793, 674 P.2d 1050, 1053 (1984); Lockwood v. Independent School Dist. No. 877, 312 N.W.2d 924, 926 (Minn. 1981); Vernon v. Seven-Eleven Stores, 547 P.2d 1300 (Okla. 1976). 
physical injuries. ${ }^{47}$ The courts' concern with the genuineness of claimed mental disabilities has been one of the major impediments to the extension of workers' compensation coverage. ${ }^{48}$ Professor Larson refers to this concern as the "how could it be real when ... it was purely mental" attitude of many judges:

This equation of "mental" with "unreal," or imaginary, or phoney, is so ingrained that it has achieved a firm place in our idiomatic language. Who has not at some time, in dismissing a physical complaint of some suffering friend or relative, airily waved the complaint aside by saying, "Oh, it's all in his head?"

The impact of this pervasive preconception on compensation decisions can be briefly stated. A high proportion of the cases display a search for something-anything - that can be called "physical" to supply the element of "reality" in the injury. ${ }^{48}$

47 See, e.g., Indemnity Ins. Co. v. Loftis, 103 Ga. App. 749, 120 S.E.2d 655 (1961) (reversing lower-court denial of claim for disability of a "psychic nature" when neurosis arose from a physical injury); Berger v. Hahner, Foreman \& Cale, Inc., 211 Kan. 541, 506 P.2d 1175 (1973) (holding compensable a traumatic neurosis that followed the loss of an eye); Hartman v. Cold Spring Granite Co., 243 Minn. 264, 67 N.W.2d 656 (1954) (holding compensable a traumatic neurosis that resulted from the cumulative effect of several injuries and corrective surgery); Montgomery Ward \& Co., Inc. v. Johnson, 645 P.2d 1051 (Okla. Ct. App. 1982) (awarding claimant compensation for post-traumatic depressive neurosis following injury to her nose).

48 Larson, supra note 3, at 1243; see, e.g., Townsend v. Maine Bureau of Pub. Safety, 404 A.2d 1014, 1019 (Me. 1979) (requiring "a higher threshold level than simply the usual and ordinary pressures that exist in any working condition would erect an appropriate buffer between the employer and a host of malingering claims").

Misplaced paternalism may be another reason why courts have been reluctant to endorse compensation for mental-mental injuries. In Hanson Buick, Inc. v. Chatham, 163 Ga. App. 127, 292 S.E.2d 428 (1982), for instance, the Court of Appeals of Georgia argued that even if the evidentiary problems of causation could be overcome, which the court greatly doubted, coverage "could make mischief not remotely intended by the beneficent objectives of [the] Act." Id. at 129, 292 S.E.2d at 430. Mental-mental coverage, it was hypothesized, would hamstring employers who want to fire or even to discipline their employees, "for fear of inciting or stimulating a nervous, mental or emotional disorder." Id.Moreover, employers would with good reason hesitate or refrain from hiring persons with histories of "shell-shock," psychiatric treatment, or even psychological counseling, for fear of being unable to discipline that employee or expose her to the vicissitudes of life, and for fear of being stuck with that employee's "life burden." Id.

A common rationale is lack of legislative guidance. See, e.g., Followill v. Emerson Elec. Co., 234 Kan. 791, 795, 674 P.2d 1050, 1053 (1984) (recognizing that legislature had recently amended statute but arguing that definitions of "personal injury" and "injury" remained unchanged); Lockwood v. Independent School Dist. No. 877, 312 N.W.2d 924, 927 (Minn. 1981) (noting that statute's 1953 amendment revealed no legislative intent to compensate such claims).

19 Larson, supra note 3, at 1243. 
The way in which courts extended coverage to psychological maladies indicates that the courts were less concerned with making principled determinations of the kinds of injuries that should be compensable and were more concerned with questions of proof. ${ }^{50}$ Sudden-stimulus cases so sufficiently resembled physical-accident cases that courts were able to analogize the two. ${ }^{51}$ The burden of sidestepping statutory language was heavy enough, and the courts that did so limited their liberal interpretation of the statutes to "safe" cases. For example, it would matter little to a court that a blinding flash of light flared fifteen feet away from a worker or that a ten-ton weight that fell from a great height narrowly missed. What would count to the court was the fact that such events actually occurred; the event's evidentiary value in proving causation reassured courts that the injuries were genuine and workrelated.

\section{ChoosIng the APPropriate Standard}

Having reviewed the policies supporting workers' compensation schemes as well as the evolution of judicial treatment of mental-injury claims, we can now determine which test-the unusual-stress test or the objective causal-connection test-is more appropriate. A test requiring that a simple causal connection be established between the alleged gradual stressors objectively existing in the workplace and the alleged mental illness is the best method for identifying injuries that should be compensated. Two arguments support this conclusion: (1) only the objective causal-connection test adequately advances the policies underlying workers' compensation and (2) the unusual-stress test is premised on a misguided view of causation.

\section{A. Workers' Compensation Policy}

The first policy consideration weighing in favor of the objective causal-connection test and against the unusual-stress test is that the latter violates the fundamental premise in workers' compensation law that the employer takes the employee as she finds her. ${ }^{52}$ Generally, workers'

so See Joseph, The Causation Issue in Workers' Compensation Mental Disability Cases: An Analysis, Solutions, and a Perspective, 36 VAND. L. REv. 263, 289-96 (1983).

s1 See 1B A. LARSON, supra note 3, § 42.21; Joseph, supra note 50, at 287.

521 A. LARson, supra note 3, § 12.20; see Kelly's Case, 462 N.E.2d 348, 350 (Mass. Ct. App. 1984) (stating that "employer must take the worker as is with existing disabilities"), aff d, No. S-3591 (Mass. May 6, 1985); Simon v. R.H.H. Steel Laun: dry, Inc., 25 N.J. Super. 50, 55-56, 95 A.2d 446, 448, affd per curiam, 26 N.J. Super. 598, 98 A.2d 604 (1953) ("[I]nherent perplexities [of the claimant] cannot be 
compensation law protects the "eggshell skull" plaintiff-a worker who is more predisposed to injury than the average worker.

Yet judicial requirements that a worker prove she was exposed to some sort of unusual or extraordinary stress do deny benefits to those who are predisposed to mental injury. A comparison of rulings using the causal-connection test and the unusual-stress test demonstrates this. State Accident Insurance Fund Corp. v. Shilling, ${ }^{53}$ decided by the Oregon Court of Appeals, and Sloss v. Industrial Commission, ${ }^{\text {s4 }}$ an Arizona case, each involved a worker who had succumbed to the continual stress and strain of a demanding job. The Arizona court denied a highway patrolman's request for compensation, arguing that the claimant experienced what was only "the usual ordinary and expected incidents of his job." ${ }^{\text {OS5 }}$ Faced with a similar claim by a motor vehicle department office worker, the Oregon court awarded compensation. ${ }^{56}$ The court acknowledged that the claimant may have been more susceptible to the working conditions than others might have been, ${ }^{57}$ but it based its decision squarely on the fact that she had incurred a true work-related mental injury: "The question is not whether claimant's perception of overwork was accurate or whether claimant was overworked as judged by a standard of what would constitute overwork to the average person on her job. The question is whether there were stress-causing pressures on her job that were 'real." "'s8

The Shilling decision is more consistent with the workers' compensation goal of coverage for all workers. The stressful work environment is analogous to a slippery floor, for it is just as capable of injuring those unlucky enough to be ill-suited to the situation. A worker predisposed to mental reactions to stress should not be denied recovery any more than a worker predisposed to certain physical injuries, and the fact that an average worker might not experience any ill effects from such stress should be irrelevant. As the New York Court of Appeals has suggested,

[T]here is nothing in the nature of a stress or shock situation which ordains physical as opposed to psychological injury. The determinative factor is the particular vulnerability of an individual by virtue of his physical make up. In a given situ-

permitted to defeat an award where the requisite standards of proof have otherwise been met.").

6s 66 Or. App. 600, 675 P.2d 1081 (1984).

s4 121 Ariz. 10, 588 P.2d 303 (1978).

ss Id. at 12, 588 P.2d at 305.

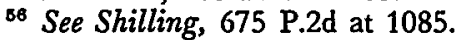

st See id. at 1081 .

58 Id. at 1084 . 
ation one person may be susceptible to a heart attack while another may suffer a depressive reaction. In either case the result is the same-the individual is incapable of functioning properly because of an accident and should be compensated under the Workmen's Compensation Law. ${ }^{59}$

The second policy consideration favoring the objective causation test arises from the system's objective of offering unqualified protection to workers who suffer any kind of incapacitating injuries during the course of employment. All work-related injuries, whether mental or physical, should be redressed. ${ }^{60}$ Seen in this light, the causal-connection test is a better measure. While the unusual-stress test often will bar recovery by workers with genuine work-related disabilities-gradualstress injuries, for example-the objective causal-connection test, by making compensation possible for many of these claimants, better comports with the goal of universal coverage. As the Hawaii Supreme Court concluded in Royal State National Insurance Co. v. Labor $\mathcal{E}^{\circ}$ Industrial Relations Appeal Board, ${ }^{\mathbf{1}}$

In today's highly competitive world it cannot be doubted that people often succumb to mental pressures resulting from their employment. These disabilities are as much a cost of the production process as physical injuries. The humanitarian purposes of the Workmen's Compensation Law require that indemnification be predicated not upon the label assigned to the injury received, but upon the employee's inability to work because of impairments flowing from the conditions of his employment. ${ }^{62}$

The important question under workers' compensation law should be whether the injury arose out of and occurred in the course of employment. If such a connection exists, benefits should be awarded. ${ }^{63}$ To

30 Wolfe v. Sibley, Lindsay \& Curr Co., 36 N.Y.2d 505, 510, 330 N.E.2d 603, 606, 369 N.Y.S.2d 637, 641 (1975).

${ }_{60}$ Indeed, most commentators agree that psychiatric theory does not support the legal distinction between "physical" injuries and "mental" injuries. See, e.g., 1B A. LARSON, supra note 3, § 42.23(a); Comment, supra note 1, at 1137.

6153 Hawaii 32, 487 P.2d 278 (1971).

62 Id. at 38,487 P.2d at 282 (footnote and citations omitted).

${ }^{63}$ Systems that limit compensation to cases in which employees experience traumatic or extraordinary events may encourage employees to create such events:Use of the time and place distinction suggests a judicial belief that mental disability may legitimately follow some traumatic shock but is imagined or faked in its absence. However, this practice may compound the incentive problem it is designed to combat. A worker who can be compensated only in the case of a traumatic event has an incentive to provide one; insistence on time and place documentation may well encourage more 
operate in an unbiased manner, the workers' compensation system must serve as a potential source of protection for all workers, regardless of the manner in which their injuries develop. ${ }^{64}$

\section{B. Causation and Legitimacy}

The search for an objective measure of an inherently subjective injury is at the heart of the problem surrounding the compensation of gradual-stress injuries. A serious shortcoming of the unusual-stress test is that it is predicated on the fallacious belief that the existence of extraordinary or unusual events assures that subsequent mental injuries are genuine and work-related and on the converse belief that the absence of such events indicates that the alleged injuries are not genuine or work-related.

Judicial reliance on tangibility as one of the indicia of an injury's genuineness is misguided. ${ }^{65}$ As one commentator has noted, "The existence of a mental impact stimulus on unusual excessive mental employment stresses ... does not medically assure the genuineness of the causal relation between a worker's mental disability and his employment any more than does the existence of a physical impact." ${ }^{\text {"66 }}$ And, although the concern over fraudulent claims is valid, ${ }^{67}$ professionals may be able to detect certain feigned psychoneurotic reactions more easily than some more commonly feigned physical injuries. ${ }^{68}$

accidents.

Staten \& Umbeck, Compensating Stress-Induced Disability: Incentive Problems, in SAFETY AND THE WORK FORCE: INCENTIVES AND Disincentives IN WORKER' COMPENSATION 103, 107 (J. Worrall ed. 1983).

64 Cases in Minnesota demonstrate the injustice of compensating workers for physical injuries caused by mental stimuli while not compensating them for mental injuries caused by mental stimuli. In Lockwood v. Independent School Dist. No. 877, 312 N.W.2d 924 (Minn. 1981), a high school principal was mentally disabled by the constant pressures of his job and was forced to take a permanent medical leave of absence. The Minnesota Supreme Court denied him disability benefits, explaining that mental illnesses caused by job stresses without physical trauma are not compensable under Minnesota law. See id. at 926-27. Yet, had stress caused the principal to suffer a fatal heart attack while at work or motivated him to kill himself while on a school outing, he would have been covered by the law. See Aker v. State, 282 N.W.2d 533 (Minn. 1979) (holding compensable a heart attack caused by mental stress); see also Egeland v. City of Minneapolis, 344 N.W.2d 597 (Minn. 1984) (stating that a stressinduced ulcer is compensable; stress-caused depression is not).

${ }^{65}$ Surprisingly, Professor Larson has recommended Wisconsin's unusual-stress requirement as the most straightforward means of determining whether a gradualstress injury satisfies the normal "arising out of employment" inquiry. See 1B A. LARsoN, supra note $3, \S \S 38.81,42.23(\mathrm{~b})$.

${ }_{68}$ Joseph, supra note 50, at 305; see Comment, supra note 1, at 1137-38.

67 See Lasky, Psychiatry and California Workers' Compensation Laws: A Threat and a Challenge, 17 CAL. W.L. REv. 1, 1 (1980).

es See Comment, supra note 1, at 1137. 
Similarly, although the relationship between a mental illness and the workplace can be tenuous, it is not entirely clear that the presence of a physical, as opposed to a mental, stimulus does anything more to guarantee that there is a causal connection between the injury and the employment. Since a physical stimulus is no more likely to trigger a psychoneurotic reaction than a mental stimulus, ${ }^{8 \theta}$ insistence on the presence of a physical stimulus is of little use to courts that are properly concerned about the legitimacy of claimed injuries.

Admittedly, identifying the source of mental illness can be, at best, a difficult task..$^{70}$ However, requiring a claimant to prove that the stress that caused her mental breakdown was unusual is a clumsy means by which to prove causation. The levels of stress in occupations vary, ${ }^{71}$ and to require a worker in a highly stressful occupation to prove that she was subject to unusual stress may be unfair, particularly when the amount of stress normally present in her work is clearly sufficient to cause mental trauma. Similarly, the worker in a low-stress profession may find the unusual-stress standard easy to meet, even though as an objective matter the level of such unusual stress may be less than an employee in another occupation might usually suffer.

The objective causal-connection test is superior for handling gradual-stress claims, for it assures that all work-related injuries are redressed and, if properly administered, limits compensation to legitimate claims. Undoubtedly some claimants will attempt to recover for feigned mental injuries or mental injuries unrelated to work, but it is preferable to adopt a broad rule and administer it closely than to allow the fear of overcoverage to compromise the workers' compensation system as a whole. As one commentator has noted,

[O]nce a causal nexus is established between the injury and the trauma, ancient notions of personal injury should be abandoned and replaced by the modern doctrine which merely requires industry to pay for the ills it causes. If a causal connection is shown, there is no logical basis to deny compensation to a claimant who would be otherwise mentally sound, but for his employment .... .

Finally, states that employ the causal-connection test can guard against fraudulent claims by adopting evidentiary safeguards. Pennsyl-

69 See id..

70 See Joseph, supra note 50, at 271-73; Comment, supra note 1, at 1142-43.

${ }^{71}$ See C. Cooper \& J. Marshall, White Collar and Professional Stress (Wiley Series on Studies in Occupational Stress 1980) (surveying stress in various white-collar occupations).

72 Note, supra note 34, at 304 (footnote omitted). 
vania, for instance, requires that, because of the highly subjective nature of psychological injuries, where "there is no obvious causal relationship between a claimant's work and his injury, he must present unequivocal medical testimony to establish the causal connection." And claimants in New Jersey must offer objective evidence that forces in the workplace were to a material degree factors contributing to the mental illness. ${ }^{34}$ The injury "'must be due in some realistic sense and material degree to a risk reasonably incidental to the employment; the [onset] must issue from or be contributed to by conditions which bear some essential relation to the work or its nature." "7s

\section{CONCLUSION}

A worker's allegation that her job has caused a disabling mental illness is troublesome, whether it is alleged that the disability was caused by a physical accident, a sudden mental stimulus, or a gradual mental stimulus. Advances in medical knowledge have revealed that the workplace is a significant source of mental injuries, yet many jurisdictions have been slow to extend workers' compensation to workers who suffer these injuries, particularly to those workers who incur gradualstress injuries. Of the two tests relied upon by jurisdictions that allow compensation for gradual-stress injuries, the objective causation test is more appropriate. It is more consistent with the policies underlying workers' compensation schemes, and it does not incorporate the faulty event-causation bias implicit in the unusual-stress test.

The treatment of mental disorders by workers' compensation law has undergone several phases in its evolution. The adoption of the simple causal-connection test should be the next stage in that evolutionary process.

73 Kitchen v. Workmen's Compensation Appeal Bd., 73 Pa. Commw. 289, 294, 458 A.2d 631, 634 (1983).

74 See Williams v. Western Elec. Co., 178 N.J. Super. 571, 585, 429 A.2d 1063, 1071 (1981).

${ }_{75}$ Id. at 585, 429 A.2d at 1070 (quoting Walck v. Johns-Manville Prods. Corp., 56 N.J. 533, 556, 267 A.2d 508, 521 (1970)). Courts fearful of an onslaught of fraudulent claims might do well to listen to Professor Larson's reassurance in a related area: If any court is disposed to worry about whether abandoning the unusual-exertion interpretation . . . would "open the floodgates," it might find reassurance in the fact that getting an . .. award in [states that have eliminated this requirement] is no "pushover." The difference is that the battle is avowedly fought out on the fundamental causation issue.

1B A. LARSON, supra note $3, \S 38.83$. 
